\title{
PENGARUH NET PROFIT MARGIN TERHADAP NILAI PERUSAHAAN DENGAN RETURN ON ASSETS SEBAGAI VARIABEL INTERVENING PADA PERUSAHAAN YANG TERDAFTAR DI JAKARTA ISLAMIC INDEX
}

\section{Hasni Fadilah, Rika Lidyah dan Deky Anwar}

Universitas Islam Negeri Raden Fatah Palembang, Indonesia

Email: hasnifadilah11@gmail.com, rikalidyah_uin@radenfatah.ac.id dan dekyanwar_uin@radenfatah.ac.id

\section{Abstract}

The purpose of this study was to determine the effect of the variable net profit margin on firm value with return on assets as an intervening variable in companies listed on the Jakarta Islamic index. This research uses secondary data, with the data collection method using the documentation method and the sample used is 28 companies registered in JII with the period 2015 to 2018. This research uses Statistical Product and Service Solutions (SPSS). The results obtained in this study are the influence of net profit margin on firm value: there is an effect of net profit margin on return on assets: return on assets affects firm value and there is an effect of return on assets as a mediation between net profit margin and firm value.

Keywords: net profit margin; company value; return on asset

\begin{abstract}
Abstrak
Tujuan penelitian ini untuk mengetahui pengaruh variabel net profit margin terhadap nilai perusahaan dengan return on asset sebagai variabel intervening pada perusahaan yang terdaftar di Jakarta Islamic index. penelitian ini menggunakan data sekunder, dengan metode pengumpulan data menggunakan metode dokumentasi dan sampel yang di gunakan yaitu 28 perusahaan yang terdaftar di JII dengan periode tahun 2015 sampai tahun 2018. Penelitian ini menggunakan Statistical Product and Service Solutions (SPSS). Hasil yang diperoleh pada penelitian ini yaitu adanya pengaruh antara net profit margin terhadap nilai perusahaan: adanya pengaruh net profit margin terhadap return on asset: return on asset berpengaruh terhadap nilai perusahaan dan adanya pengaruh return on asset sebagai mediasi antara net profit margin terhadap nilai perusahaan
\end{abstract}

Kata Kunci: net profit margin; nilai perusahaan; return on asset

\section{Pendahuluan}

Pasar modal merupakan salah pasar untuk berbagai instrumen keuangan jangka panjang yang termasuk kedalam transaksi jual beli yang sangat penting bagi perekonomian suatu Negara (Juliati, 2015). Salah satu pengukuran kinerja perusahaan adalah dengan melihat nilai perusahaan (Fidhayatin, 2012). Pengukuran ini dapat

$\begin{array}{ll}\text { How to cite: } & \text { Fadilah, Hasni, et.al (2021) Pengaruh Net Profit Margin terhadap Nilai Perusahaan dengan Return on } \\ & \text { Assets Sebagai Variabel Intervening pada Perusahaan yang Terdaftar Di Jakarta Islamic Index, Syntax } \\ & \text { Literate: Jurnal Ilmiah Indonesia. 6(4). http:// 10.36418/syntax-literate.v6i4.2425 } \\ \text { E-ISSN: } & \text { 2548-1398 } \\ \text { Published by: } & \text { Ridwan Institute }\end{array}$


menggambarkan minat investor akan membeli saham perusahaan yang jika semakin tinggi maka berarti manajemen saham perusahaan berhasil memaksimalkan aktiva yang dimiliki. Menurut (Dewi \& Wirajaya, 2013) nilai perusahaan merupakan nilai pasar dari suatu ekuitas perusahaan ditambah dengan nilai pasar hutang. Dengan demikian, penambahan dari jumlah ekuitas perusahaan dengan hutang perusahaan dapat mencerminkan nilai perusahaan. Akan tetapi dalam penelitian ini hanya dua faktor yang dibahas yaitu profitabilitas dan struktur modal. Seperti penelitian yang dilakukan oleh, (Santosa, Chabachib, \& Pengestuti, 2016) yang menyatakan bahwa adanya pengaruh return on asset terhadap nilai perusahaan dengan devident payout rasio sebagai variabel intervening. Perbedaan terhadap penelitian ini idalah digunakannya variabel return on asset sebagai inetervening.

Membuat keputusan saat akan berinvestasi yang berfokus pada hasil laporan keuangan sebuah perusahan tidak akan menjamin bahwa keputusan investasi akan tepat (Imaniar \& Kurnia, 2016). Banyak investor yang berinvestasi pada sebuah perusahan hanya dengan melihat keutungan yang ditawarkan oleh prusahaan tanpa tau manajemen perusahan mengalami keutungan atau kerugian. Fenomenannya adalah terdapat banyak perusahaan yang membuat citra perusahaan hanya bagus dari luarnya saja dengan memberikan gambaran return saham yang tinggi, padahal hanya mengedepankan laba dan aset dalam mebesarkan perusahaan. Pada saat ini banyak juga perusahaan baru yang tumbuh besar meskiapun laporan keungan menujukan kerugian dengan membangun citra value dari perusaahan yang tinggi karena nilai nya tingga maka banyak pihak yang akan tertarik untuk berinvestasi.

\section{A. Signaling Theory}

Informasi yang diberikan oleh perusahaan merupakan hal penting karena pengaruhnya terhadap keputusan investasi pihak diluar perusahaan terkait, informasi ini penting bagi investor dan pelaku bisnis karena pada hakikatnya memberikan keterangan, catatan atau gambaran, baik untuk keadaan masa lalu, saat ini maupun masa yang datang baik bagi kelangsungan kehidup sebuah perusahaan dan bagaimana efeknya bagi perusahaan.

Perusahaan seringkali dihadapkan pada perbedaan kualitas antar sesama perusahaan seperti kualitas strategi bisnis, informasi, sumber daya, dan juga kualitas pelaporan keuangan, adanya perbedaan tersebut, perusahaan harus memberikan sinyal kepada investor. (Scott: 2009) dalam (Sari, 2016) mendefinisikan sinyal sebagai: "A signal is an action taken by a high-type manager that would not be rational if that manager was low-type". High type manager ialah manajer pada perusahaan yang dipersepsikan memiliki kualitas tinggi oleh investor. Manajer seperti ini dapat mengirimkan sinyal dengan biaya yang lebih murah yang tidak dapat ditiru oleh low-type manager.

Teori sinyal menjelaskan mengapa perusahaan mempunyai dorongan untuk memberikan informasi laporan keuangan pada pihak eksternal (Gumanti, 2009). Dorongan perusahaan untuk memberikan informasi karena terdapat asimetri informasi antara perusahaan dan pihak luar karena perusahaan mengetahui lebih 
banyak mengenai perusahaan dan prospek yang akan datang daripada pihak luar (investor dan kreditor). Dengan mengunakan metode ini akan lebih mudah bagi investor dalam memilih perusahaan untuk berinvestasi sehingga mengetahui perusahaan mana yang membagikan devident lebih tinggi sehingga mendapat keuntungan.

\section{Metode Penelitian}

\section{A. Jenis penelitian dan Data}

Jenis penelitian yang digunakan dalam penelitian ini adalah penelitian kuantitatif (Sugiyono, 2015). Penelitian kuantitatif adalah jenis penelitian yang menghasilkan penemuan-penemuan yang dapat dicapai atau diperoleh dengan menggunakan prosedur-prosedur statistik atau cara-cara lain dari kuantifikasi (pengukuran).

Data penelitian yang digunakan adalah kuantitatif berbentuk data rasio atau interval yang merupakan data-data sekunder yang diperoleh dan dikumpulkan dari berbagai sumber terkait. Jika dilihat dari waktu pengumpulannya, maka jenis data pada penelitian ini menggunakan data panel (gabungan antara dua data time series dan data cross section) yang diambil dalam periode 2015-2018 dengan menggunakan aplikasi SPSS 23 (Sarwono, 2017).

\section{B. Teknik Pengumpulan Data}

Sesuai dengan jenis data yang diperlukan yaitu data sekunder, maka metode pengumpulan data dalam penelitian ini adalah dengan menggunakan metode dokumentasi. Menurut (Sujarweni, 2015) metode dokumentasi adalah metode dalam pengumpulan data yang dilakukan dengan cara mempelajari atau mengumpulkan catatan atau dokumen yang berkaitan dengan masalah yang diteliti. Pengambilan data melalui metode dokumentasi ini bersumber dari sumber data tertulis, seperti buku, jurnal, arsip, annual report perusahaan, atau data statistic.

\section{Populasi dan Sampel}

Populasi adalah wilayah generalisasi yang terdiri atas objek atau subjek yang mempunyai karakteristik dan kualitas tertentu yang ditetapkan oleh peneliti untuk dipelajari dan kemudian ditarik kesimpulannya. Dari definisi tersebut, maka populasi dalam penelitian ini adalah perusahaan yang terdaftar di Jakarta Islamic Index sesuai dnegan kebutuhan penelitian periode 2015-2018.

Sampel adalah bagian dari jumlah dan karakteristik yang dimiliki oleh populasi tersebut. Untuk itu sampel yang diambil adalah sebagai representatif pada penlitian ini sampel yang digunakan sebanyak 28 perusahaan dari 35 perusahaan yang terdaftar di JII karena sisanya tidak memenuhi kriteria dalam penelitian. 
Pengaruh Net Profit Margin terhadap Nilai Perusahaan dengan Return on Assets Sebagai Variabel Intervening pada Perusahaan yang terdaftar Di Jakarta Islamic Index

\section{Hasil dan Pembahasan}

Tabel 1

\begin{tabular}{llllll}
\hline \multicolumn{1}{l}{ Descriptive Statistics } & & & & \\
\hline & $\mathrm{N}$ & Minimum & Maximum & Mean & Std. Deviation \\
\hline NPM (X) & 100 & .36 & 38.25 & 13.4049 & 8.64585 \\
\hline PBV (Y) & 100 & .06 & 82.44 & 5.0230 & 11.27467 \\
\hline ROA (Z) & 100 & .23 & 46.66 & 10.0964 & 8.56446 \\
\hline
\end{tabular}

Sumber : Data statistik di olah, 2021

Tabel 1 menunjukkan variabel net profit margin memiliki nilai minum sebesar 0,36 nilai maksimum 38,25 dan nilai rata-rata sebesar 13,4049 yang berarti net profit margin perusahaan yang terdaftra di Jakarta islamic index dalam penelitian ini cuku baik. Variabel nilai perusahaan yang menggunakan nilai price book value memiliki nilai minimum 0,06 dan maksimum 82.44 dan nilai rata-rata 5.0230 yang berarti price book value dalam penelitian ini memiliki nilai yang baik. Variabel return on asset dengan nilai minimum 0,23 dan nilai maksimum 46,66 memiliki nilai rata-rata 10.0964 menyatakan bahwa return on asset dalam penelitian ini baik.

\section{Tabel 2}

Coefficients $^{\mathrm{a}}$

\begin{tabular}{lllllll}
\hline & & \multicolumn{2}{l}{$\begin{array}{l}\text { Unstandardized } \\
\text { Coefficients }\end{array}$} & $\begin{array}{l}\text { Standardized } \\
\text { Coefficients }\end{array}$ & \multicolumn{2}{l}{ Sig. } \\
\cline { 2 - 6 } Model & $\mathrm{B}$ & Std. Error & Beta & & \\
\hline 1 & (Constant) & -1.718 & 1.310 & & -1.311 & .193 \\
\cline { 2 - 7 } & NPM (X) & -.400 & .093 & -.306 & -4.285 & .000 \\
\cline { 2 - 6 } & ROA (Z) & 1.198 & .094 & .910 & 12.727 & .000 \\
\hline
\end{tabular}

a. Dependent Variable: PBV (Y)

Sumber : Data Statistik di olah, 2021

Nilai konstanta -1.718 yang bearti bahwa tanpa adanya net profit margin dan return on asset maka nilai perusahaan yang terdaftar di Jakarta Islamic index tidak dapat dikatakan baik. Tetapi dengan adanya net profit margin dan return on asset maka akan menunjang nilai perusahaan menjadi lebih baik. 
Tabel 3

ANOVA

\begin{tabular}{lllllll}
\hline \multirow{2}{*}{ Model } & & Sum & of & & & \\
\hline \multirow{2}{*}{1} & & Squares & df & Mean Square & F & Sig. \\
\cline { 2 - 7 } & Regression & 7994.710 & 2 & 3997.355 & 84.476 & $.000^{\mathrm{b}}$ \\
\cline { 2 - 7 } & Residual & 4589.999 & 97 & 47.320 & & \\
\cline { 2 - 7 } & Total & 12584.709 & 99 & & & \\
\hline
\end{tabular}

a. Dependent Variable: PBV (Y)

b. Predictors: (Constant), ROA (Z), NPM (X)

Sumber : Data statistik di olah , 2021

Berdasarkan tabel 3 anova di atas diperoleh nilai $\mathrm{F}$ hitung sebesar 84.476 dengan niai signifikan $0.000<0,05$ yang berarti hipotesis diterima sehingga dapat dijelaskan bahwa variabel net profit margin berpengaruh terhadap nilai perusahaan dan return on asset pada perusahaan yang terdaftar di Jakarta Islamic index.

Tabel 4

Model Summary ${ }^{b}$

\begin{tabular}{lllll}
\hline Model & $\mathrm{R}$ & R Square & $\begin{array}{l}\text { Adjusted } \\
\text { Square }\end{array}$ & $\begin{array}{l}\text { R Std. Error of } \\
\text { the Estimate }\end{array}$ \\
\hline 1 & .797 & .635 & .628 & 6.87892 \\
a & & \\
\hline \multicolumn{7}{l}{ a. Predictors: (Constant), ROA (Z), NPM (X) } \\
\hline \multicolumn{2}{l}{ b. Dependent Variable: PBV (Y) } \\
\hline
\end{tabular}

Sumber : Data statistik di olah , 2021

Berdasarkan tabel 4 diatas diketahui nilai R sebesar $0.797>0,05$ sehingga korelasi kuat karena $>0,05$ yang berarti bahwa terdapat hubungan yang positif antara net profit margin dan return on asset terhadap nilai perusahaan yang terdaftar di Jakarta Islamic index. Kemudian diketahui nilai adjusted $R$-Square 0,628 yang bearti variabel secara bersama-sama mampu menjelaskan variasi yang terjadi sebesar 62,8\% sedangkan sisanya $37,2 \%$ dijelaskan oleh variabel lain diluar variabel penelitian.

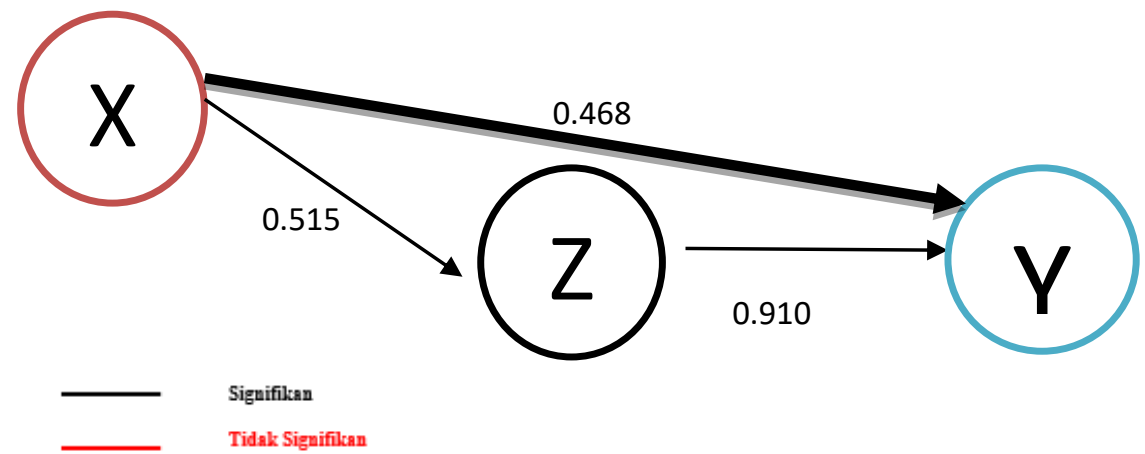

Gambar 1 Analisi Jalur 
Pada gambar 1 diperoleh hasil direct effect $\mathrm{X}$ terhadap $\mathrm{Z}$ sebesar 0.515 yang menyatakan bahwa adanya pengaruh antar kedua variabel, kemudian direct effect $\mathrm{Z}$ terhadap Y sebesar 0.910 menyatakan bahwa terdapat pengaruh yang signifikan terhadap kedua variabel yakni return on aset terhadap nilai perusahaan yang di proksi oleh price book value dan indirect fffect X terhadap Y melalui Z sebesar 0.515 x 0.910 $=0.468$ yang menyatakan bahwa kedua variabel return on aset memeprkuat hubungan antara variabel net proft margin terhadap nilai perusahaan.

\section{A. Pengaruh Net Profit Margin terhadap Nilai Perusahaan}

H1 menyatakan bahwa terdapat pengaruh net profit margin terhadap nilai perusahaan berdasarkan hasil analisis terdapat pengaruh yang signifikan dengan nilai $\mathrm{t}-4,285$ dengan nilai signifikansi $0,000<0,05$ maka variabel memiliki pengaruh yang positif. Net porfit margin pada dasarnya menunjukan pendapatan bersih perusahaan atas penjualan sehingga jika adanya tranfaransi dari sebuah perusahaan seperti pendapatan bersih akan meningkat nilai perusahaan yang akan manarik perhatian seorang investor untuk berinvestasi.

\section{B. Pengaruh return on asset terhadap nilai perusahaan}

Dari perhitungan uji secara parsial diperoleh nilai t hitung 12,727 dengan nilai signifikansi 0,000. Karena nilai signifikansi lebih kecil dari 5\% maka hipotesis diterima. (Brigham \& Houston, 2011) dikarenakan semakin tinggi profitabilitas suatu perusahaan menunjukan semakin baik manajemen dalam menjalankan operasi perusahaan. Perusahaan yang memiliki profitabilitas yang tinggi biasanya akan meningkatkan nilai sebuah perusahaan. Pada hasil penelitian ini dapat diketahui bahwa return on asset berpengaruh signifikan terhadap nilai perusahaan.

\section{Pengaruh return on asset memediasi net profit margin terhadap nilai perusahaan}

H3 menyatakan bahwa return on asset memediasi net profit margin terhadap nilai perusahaan. Dapat dilihat nilai net profit margin terhadap return on asset dengan nilai 0,515 menunjukan pengaruh yang signifikan. Selanjutnya variabel return on asset terhadap nilai perusahaan dengan nilai 0,910 menunjukan pengaruh yang positif. Nilai return on asset memediasi net profit margin terhadap nilai perusahaan yaitu sebesar 0,468 . Hasil penelitian didukung penelitian yang dilakukan oleh (Misran \& Chabachib, 2017) tentang net profit margin dan total asset turnover terhadap price book value dengan return on asset sebagai variabel intervening pada perusahaan properti dan real estate yang terdaftar di BEI.

\section{Kesimpulan}

Pada saat ini banyak juga perusahaan baru yang tumbuh besar meskipun laporan keungan menujukan kerugian dengan membangun citra value dari perusaahan yang tinggi karena nilai nya tingga maka banyak pihak yang akan tertarik untuk berinvestasi. Pada penelitian ini menyatakan bahwa terdapat pengaruh net profit margin terhadap nilai perusahaan berdasarkan hasil analisis terdapat pengaruh yang signifikan dengan nilai $t-4,285$ dengan nilai signifikansi $0,000<0,05$ maka 
variabel memiliki pengaruh yang positif, kemudian pengaruh return on aset terhadap nilai perusahaan yakni perhitungan uji secara parsial diperoleh nilai t hitung 12,727 dengan nilai signifikansi 0,000. Karena nilai signifikansi lebih kecil dari 5\% maka hipotesis diterima dan selanjutnya variabel return on asset terhadap nilai perusahaan dengan nilai 0,910 menunjukan pengaruh yang positif. Nilai return on asset memediasi net profit margin terhadap nilai perusahaan yaitu sebesar 0,468. 
Pengaruh Net Profit Margin terhadap Nilai Perusahaan dengan Return on Assets Sebagai Variabel Intervening pada Perusahaan yang terdaftar Di Jakarta Islamic Index

\section{BIBLIOGRAFI}

Brigham, \& Houston. (2011). Dasar-dasar Manajemen Keuangan. Jakarta: Salemba Empat.

Dewi, Ayu Sri Mahatma, \& Wirajaya, Ary. (2013). Pengaruh struktur modal, profitabilitas dan ukuran perusahaan pada nilai perusahaan. E-Jurnal Akuntansi, $4(2), 358-372$.

Fidhayatin, Septy Kurnia. (2012). Analisa Nilai Perusahaan, Kinerja Perusahaan Dan Kesempatan Bertumbuh Perusahaan Terhadap Return Saham Pada Perusahaan Manufaktur Yang Listing Di Bei. Stie Perbanas Surabaya. Google Scholar

Gumanti, Tatang A. (2009). Teori sinyal dalam manajemen keuangan. Manajemen Usahawan Indonesia, 38(6), 4-13. Google Scholar

Imaniar, Fitrah Qulukhil, \& Kurnia, Kurnia. (2016). Faktor-Faktor yang Mempengaruhi Ketepatan Waktu Pelaporan Keuangan Perusahaan. Jurnal Ilmu Dan Riset Akuntansi (JIRA), 5(6). Google Scholar

Juliati, Yenni Samri. (2015). Peranan Pasar Modal Dalam Perekonomian Negara. Human Falah: Jurnal Ekonomi Dan Bisnis Islam, 2(1), 95-112. Google Scholar

Misran, Medy, \& Chabachib, Mochamad. (2017). Analisis Pengaruh Der Cr Dan Tato Terhadap Pbv Dengan Roa Sebagai Variabel Intervening (Studi Pada Perusahaan Properti Dan Real Estate Yang Terdaftar Pada Bei Tahun 2011-2014). Diponegoro Journal Of Management, 6(1), 203-215. Google Scholar

Santosa, Anna Elvina, Chabachib, Mochammad, \& Pengestuti, Irene Demi. (2016). Analisis Pengaruh ROA, DER, CR, Firm Size, dan Sales Growth terhadap Nilai Perusahaan dengan Dividen Payout Ratio sebagai Variabel Mediator (Studi Pada Perusahaan Non Financial yang Terdaftar Di BEI Tahun 2010-2014). Diponegoro University. Google Scholar

Sari, Putri Andita. (2016). Pengaruh Profitabilitas, Likuiditas Dan Price Earning Ratio Terhadap Harga Saham Pada Saham Lq45 Yang Terdaftar Di Bursa Efek Indonesia 2011-2013. STIE Indonesia Banking School. Google Scholar

Sarwono, Jonathan. (2017). Mengenal Prosedur-Prosedur Populer dalam SPSS 23. Elex Media Komputindo. Google Scholar

Sugiyono, Prof. (2015). Metode penelitian kombinasi (mixed methods). Bandung: Alfabeta, 28. Google Scholar

Sujarweni, V. Wiratna. (2015). Metodologi Penelitian Bisnis \& Ekonomi. Yogyakarta: Pustaka baru press. Google Scholar 
Copyright holder :

Hasni Fadilah, Rika Lidyah dan Deky Anwar (2021)

First publication right :

Journal Syntax Literate

This article is licensed under:

(c) $(\mathrm{C})$ 